\title{
A Constructivist Approach for Introducing Undergraduate Students to Special Collections and Archival Research
}

In the last five years, a wealth of literature has been published on collaborations and practical approaches to engaging undergraduate students with special collections and archival materials. ${ }^{1}$ However, there is a gap in the literature on pedagogical approaches to teaching undergraduates with special collections. Constructivism, a learning theory, centers on the idea that students are able to construct their own meaning from their learning environment and experiences with guidance from a teacher, and that students possess prior knowledge from their own experiences. ${ }^{2}$ Prior knowledge helps to connect students to new knowledge with support from the teacher. Rather than create a learning environment that treats students as passive learners with nothing to contribute, the constructivist approach involves students in the learning process by engaging them in dialogue with the teacher and their peers, situating them through hands-on practice and helping them develop an awareness of their own learning preferences and experiences. The constructivist learning theory acts as a guide for designing lesson plans and activities. For example, when developing a lesson plan, a teacher needs to ask the following questions: how are the students connecting new content with prior knowledge and/or experiences? How are the students engaging in dialogue and prompting further inquiry or discussion on a topic? How are students situating themselves or contextualizing new knowledge? How are students developing awareness with their learning? If

1. Anne Bahde, "Taking the Show on the Road: Special Collections Instruction in the Campus Classroom," RBM: A Journal of Rare Books, Manuscripts, \& Cultural Heritage 12, no. 2 (2011): 75-88; George Thomas Kapeolos and Susan Patrick, "Teaching with the Canadian Architect Fonds: A Collaboration between Ryerson University Librarians and Instructors in Architecture Using Special Collections," Art Documentation: Bulletin of the Art Libraries Society of North America 31, no. 2 (2012): 245-62; Eleanor Mitchell, Peggy Seiden, and Suzy Taraba, Past or Portal? Enhancing Undergraduate Learning through Special Collections and Archives (Chicago, Ill.: Association of College \& Research Libraries, 2012); Melissa A. Hubbard and Megan Lotts, "Special Collections, Primary Resources, and Information Literacy Pedagogy," Communications in Information Literacy 7, no. 1 (2013): 25-38; Morgan Daniels and Elizabeth Yakel, "Uncovering Impact: The Influence of Archives on Student Learning," Journal of Academic Librarianship 39, no. 5 (2013): 414-22; Using Primary Sources: Handson Instructional Exercises, eds. Anne Bahde, Heather Smedberg, and Mattie Taormina (Santa Barbara, Calif.: Libraries Unlimited, 2014); Todd Samuelson and Cait Coker, "Mind the Gap: Integrating Special Collections Teaching," portal: Libraries \& the Academy 14, no. 1 (2014): 51-66; Educational Programs: Innovative Practices for Archives and Special Collections, ed. Kate Theimer (Lanham, Md.: Rowman \& Littlefield, 2015).

2. Preface to Constructivism: Theory, Perspectives, and Practice, ed. Catherine Twomey Fosnot (New York: Teachers College Press, 2005), ix.

*(C) 2016 by Silvia Vong (CC BY-NC [https://creativecommons.org/licenses/by-nc/4.0/]). 
all of these questions are considered and incorporated into a lesson plan, students should engage in activities or teaching strategies that elicit prior knowledge and connect them to new knowledge, improve their critical thinking and inquiry skills through discussion, and develop self-awareness.

There is pedagogical value in applying the constructivist approach to teaching with special collections. Constructivism has the potential to:

- Demystify special collections and archives for undergraduate students;

- Shift the perception of the librarian or archivist from gatekeeper to teacher;

- Develop students' skills of inquiry to produce original research. ${ }^{3}$

Constructivism entrusts the students to create their own learning experiences by participating in activities, while the teacher's role is to create an environment that prompts students to inquire, discuss, and reflect on new ideas. These kinds of actions help to demystify resources or special collections for undergraduate students. For example, a study found that rare books, manuscripts, and archival collections intimidate undergraduate students. ${ }^{4}$ By incorporating elements of the constructivist approach, such as discussions and hands-on exercises, archival materials become less of an artifact to be admired behind glass and more of an interactive learning object that can be used to further research. Assumptions about the materials can be clarified by introducing students to new concepts and discussions. The myth that books, manuscripts, and archival materials are inaccessible to undergraduates can be dispelled through hands-on exercises and use of the materials for research.

The special collections and archives environment offers a unique one-on-one learning opportunity for undergraduate students with the support of the librarian or archivist. Zhou emphasizes the important role a special collections librarian or archivist has in engaging with students and their value in ensuring students' success in conducting research. ${ }^{5}$ Special collections librarians and archivists will have various strategies at their disposal when teaching students how to search, evaluate, and analyze rare books or archival materials. For example, undergraduate students may ask the archivist or rare books librarian about items for courses. Rather than provide facts or descriptions to the students, the librarian or archivist can engage

3. Alyssa Friend Wise and Kevin O’Neill, “Beyond More Versus Less: A Reframing of the Debate on Instructional Guidance," in Constructivist Instruction: Success or Failure? eds. Sigmund Tobias and Thomas M. Duffy (New York, Routledge, 2009), 82-105.

4. Susan Summerfield Hammerman, Barbara Kern, Rebecca Starkey, and Anne Taylor, "College Students, Cookies and Collections: Using Holiday Study Breaks to Encourage Undergraduate Research in Special Collections," Collection Building 25, no. 4 (2006): 145.

5. Xiaomu Zhou, "Student Archival Research Activity: An Exploratory Study," American Archivist 21, no. 2 (2011): 485 . 
the students in an inquiry-based discussion to encourage the student to further seek answers and conduct further research, thus shifting the role of the librarian or archivist from gatekeeper to teacher.

Special collections also offer an opportunity for undergraduate students to hone their skills of inquiry and inspire them to produce original research. Levy and Petrulis found that undergraduate students were interested in producing research with their own ideas and discoveries. ${ }^{6}$ In their qualitative study, students were interviewed and asked to respond to questions related to their learning and their experiences with inquiry and research, including challenges. ${ }^{7}$ The students described their research experience as an empowering learning experience and were able to view themselves as knowledge producers. For example, one student likened the experience of completing a research project as growing up and developing independence as a learner as well as a researcher in the field. ${ }^{8}$ The rare books and archival items available in special collections offer students the opportunity to explore original research ideas using unique materials and to develop their identities as knowledge producers while drawing from a range of resources.

In the age of Google, undergraduate students can easily access different web sources that provide summaries and overviews on various topics. However, some items in rare book collections and archives may lack online surrogates or secondary sources. For example, the John M. Kelly Library has a travel diary written from 1832 to 1834 by an anonymous creator. ${ }^{9}$ There are no secondary sources, either scholarly and popular, to provide information about the item or creator. As a result, this item often requires students to analyze the text for information as well as develop a hypothesis on the creator. This is an excellent learning opportunity for students to inquire and evaluate these sources of information with guidance and instruction from the librarian or archivist. A first-year student who comes across a unique illuminated manuscript may need guidance on how to approach the item. Often they may ask, "How do I start?" A librarian or archivist can begin with a guide-based discussion, leading them to develop questions for the item. Special collections and archives have great potential to nurture students' curiosity. Therefore, the use of a learning framework in that environment could transform it from just a physical space that houses books, papers, and objects to a place filled with discussion and interaction between students and teachers.

6. Philippa Levy and Robert Petrulis, "How Do First-Year University Students Experience Inquiry and Research, and What Are the Implications for the Practice of Inquiry-Based Learning," Studies in Higher Education 37, no. 1 (2012): 94.

7. Ibid., 90 .

8. Ibid., 95 .

9. Excursion to Scotland, 1832, University of St. Michael's College in the University of Toronto, available online at https: / / archive.org/details/ excursiontoscotlo0anonuoft [accessed 22 August 2016]. 
To focus the discussion, this article will apply the constructivist theory to a creditbearing course that introduces undergraduate students to research using items from special collections. ${ }^{10}$ The article frames the discussion of the activities around four main characteristics of constructivism. A student is engaged with learning through the constructivist approach when they are able to:

- Connect with prior and new information to build knowledge;

- Inquire into an issue or topic through social interaction;

- Contextualize their new knowledge through an authentic task; and

- Reflect and acknowledge their learning experience. ${ }^{11}$

Each characteristic will be further defined, followed by an explanation of how an activity addresses the characteristics and any challenges that may arise. Finally, this article will include a discussion of future research on this topic.

\section{Literature Review \\ Constructivism and Learning}

Jean Piaget was a seminal figure in the constructivist movement. He initially presented the idea of constructing knowledge from a biology perspective and thereby laid the groundwork for future biologists and psychologists. ${ }^{12}$ Other theorists who followed after Piaget became proponents of constructivism or some form of it and introduced new aspects of constructivism. ${ }^{13}$ Many of these theories laid the groundwork for the constructivist movement. For example, Piaget's idea of

10. The constructivist learning theory can still be applied in a one-shot instruction session, although realistically, depending on the amount of time or the faculty member's request, there is a limited number of activities. If a librarian or archivist were to apply the constructivist theory in a one- or two-hour session, he or she would have to supplement the classroom talk with further learning through activities either outside of classroom time and/or virtually with online tutorials. For example, a two-hour class visit to a reading room aimed at introducing students to symbols in illuminated manuscripts may require the professor to assign a relevant reading. This reading could be used as an introduction to connect students with any prior understanding they have of symbols in texts. There could also be a hands-on activity after a talk that asks the students to analyze symbols in an illuminated manuscript in small groups with a reflective exercise at the end of the session. In a short session, a simple 3-2-1 reflection exercise can help students identify: three things they learned, two things they found challenging or did not understand, and one question they have for the instructor. Alternatively, if time is tight, an online tutorial that functions as the hands-on activity is an option for students. In that scenario, an interactive tutorial could have images of illuminated manuscripts that allow students to identify symbols and their meanings through an online test or activity.

11. David Wrap and Maureen Lewis, Extending Literacy: Children Writing and Reading Non-Fiction (New York: Routledge, 1997); Catherine Twomey Fosnot and Randall Stewart Perry, "Constructivism: A Psychological Theory of Learning," in Constructivism: Theory. Perspectives, and Practice, ed. Catherine Twomey Fosnot (New York: Teacher's College Press, 2005), 33-34; Alan Pritchard, Ways of Learning (New York: Routledge, 2009).

12. Fosnot and Perry, "Constructivism: A Psychological Theory of Learning," 8.

13. The history of constructivism is a long one that involves many theorists and a bevy of biologists and psychologists. Some key figures to study are Lev Vygotsky, Jerome Bruner, Howard Gardner, Nelson Goodman, Albert Bandura, and Lave and Wenger. Fosnot and Perry, "Constructivism: A Psychological Theory of Learning," 11. 
"constructing" meaning "from our environment" was followed by Vygotsky's theoretical contribution, which focused on the construction of knowledge through social interaction and sociocultural influences. Jerome Bruner and Albert Bandura expanded upon Vygotsky's theory to include scaffolding and emphasize the value of social interaction and learning. ${ }^{14}$ In the twentieth and twenty-first centuries, constructivism is often explored as a framework in education fields and professions related to teaching and learning. ${ }^{15}$

Walster discusses multiple instructional design theories and lightly touches on constructivism. She provides a general overview of each learning theory, followed by a discussion on which theories fit in different educational contexts. ${ }^{16}$ She also provides a brief overview of constructivism and notes that this learning theory is mostly used in an online learning environment. The overview of the learning theory is very brief, and little information is provided; however, the author discusses multiple theories, and the publication year, 1995, indicates that the topic was becoming more popular in education-related literature as well as discussions on educational reform in the United States. ${ }^{17}$

More recent literature by Jones, Flohr, and Martin also discusses constructivism as an approach to learning by providing different examples related to inquiry and the potential impact of constructivism. For example, the authors cite Angela Zhang, a high school student who pursued research and knowledge in the field of cancer by reading peer-reviewed articles and learning new terminology and, eventually, understanding more complex research. ${ }^{18}$ They provide a very detailed discussion that examines the value of using the approach. They cite studies in various disciplines ranging from a business setting (a computer company in San Diego, California) to a classroom (geology course) and provide a summary of the results. Jones, Flohr, and Martin explain that the reasoning for this structure is that their focus is on "the exploratory aspects of inquiry to move students from teacher-driven research papers to the constructivist implementation of inquiry." ${ }^{19}$

14. Lisa Oakley, Cognitive Development (New York: Routledge, 2004), 42-43; Michael Waring and Carol Evans, Understanding Pedagogy: Developing a Critical Approach to Teaching and Learning (New York: Routledge, 2015), 37-39.

15. The SAGE Encyclopedia of Action Research, eds. David Coghlan and Mary Brydon-Miller (Thousand Oaks, Calif.: SAGE Publications, 2014), 182.

16. Dian Walster, "Using Instructional Design Theories in Library and Information Science," Journal of Education for Library and Information Science 36, no. 3 (1995): 239-48.

17. Alke Martens and Dennis Maciuszek, "Balancing Instruction and Construction in Virtual World Learning," in Serious Games and Virtual Worlds in Education, Professional Development and, Healthcare, eds. Klaus Bredi and Wolfgang Bosche (Hershey, Pa.: Information Science Reference, 2013), 18; J. Wesley Null, "Is Constructivism Traditional? Historical and Practical Perspectives on a Popular Advocacy," Educational Forum 68 (2004): 180.

18. Jami L. Jones, Barbara Raley Flohr, and Mimi Stanley Martin, "Theories Holding Promise for Supporting the Constructivist Behaviors of Inquiry," School Libraries Worldwide 21, no. 2 (2015): 115-26.

19. Jones, Flohr, and Martin, “Theories Holding Promise," 116. 


\section{Constructivism in the Library Context}

The constructivist approach has demonstrated an impact on student learning in the library literature, though primarily in the context of information-seeking behavior. ${ }^{20}$ Most of the articles cite constructivist learning theory as an approach to teaching information literacy from the reference desk, to the classroom, to online tutorials. The library literature typically presents this approach as successful in engaging students with the content, and student experiences are more likely to reflect learning outcomes. ${ }^{21}$ For example, Sizemore and Marcum discuss their experiences with applying a constructivist approach in collaboration with a social work faculty member. They indicated that, in the responses from students, the presence of a librarian as a guide had a positive impact on their learning experience..$^{22}$

Char Booth discusses the importance of using learning theories and instructional strategies in the library profession. She discusses the value of learning theories in the library as a way of informing our teaching practices as well as spaces. The library itself is considered a place for learning; thus there is a need to adopt learning theories to exercise good teaching practices. ${ }^{23}$ McNeer echoes this sentiment and argues that learning theories can help librarians understand students' learning needs and "challenge their development." ${ }^{24}$ Grassian and Kaplowitz identify multiple learning theories that should be explored in information literacy instruction. They emphasize the need for a variety of learning theories to help librarians support students through different strategies. However, it is important to note that Grassian and Kaplowitz do indicate that not one theory or all theories may fit a given situation and that each theory can work in specific environments or contexts. ${ }^{25}$

Some librarians have discussed the use of constructivism using a narrative approach, providing anecdotal evidence and experience to evaluate the value of the constructivism. An example is Cooperstein and Kocevar-Weidinger, ${ }^{26}$ who are widely cited in library literature related to online learning, instructional design,

20. Carol C. Kuhlthau, "Inside the Search Process: Information Seeking from the User's Perspective," Journal of the American Society for Information Science 42, no. 5 (1991): 361-71; Shelagh K. Genuis, "Kuhlthau's Classic Research on the Information Search Process (ISP) Provides Evidence for Information Seeking as a Constructivist Process," Evidence Based Library and Information Practice 2, no. 4 (2007): 361-71.

21. Linda Sizemore and Brad Marcum, "Social Policy and Constructivism: Using Constructivist Learning Theory in Teaching Social Work Students Research Skills," The Southeastern Librarian 56, no. 3 (2008): 17-20; Jones, Flohr, and Martin, “Theories Holding Promise," 115-26.

22. Sizemore and Marcum, "Social Policy and Constructivism," 19.

23. Char Booth, Reflective Teaching, Effective Learning: Instructional Literacy for Library Educators (Chicago: American Library Association, 2011), 37-40.

24. Elizabeth J. McNeer, "Learning Theories and Library Instruction," Journal of Academic Librarianship 17, no. 5 (1991): 294.

25. Esther S. Grassian and Joan R. Kaplowitz, Information Literacy Instruction: Theory and Practice (New York: Neal-Schuman Publishers, Inc., 2009), 27-43.

26. Susan E. Cooperstein and Elizabeth Kocevar-Weidinger, "Beyond Active Learning: A Constructivist Approach to Learning," Reference Services Review 32, no. 2 (2004): 141-48. 
or teaching. They apply the constructivist approach to their teaching and use the examples of their teaching experiences. However, they note that they do not fully apply the constructivist approach to their teaching "because [they] have so much information to convey and so little time, [they] cannot let students wander as freely as in strict constructivist sessions." ${ }^{27}$ Cooperstein and Kocevar-Weidinger emphasize the need to consider learning principles so that students process new information better and build upon basic concepts. ${ }^{28}$ They cite that one challenge is the approach, which can be difficult and time consuming. However, they also note that, if designed well, constructivism can be engaging for the students and help to better the learning experience. ${ }^{29}$ Their success is anecdotal, but it is often difficult to assess the success of a student's learning experience, especially for one-shot sessions. Sizemore and Marcum refer to qualitative feedback collected from their session. While they do not analyze or present this feedback, they indicate that, overall, students and faculty are satisfied with the use of constructivist learning theory. ${ }^{30}$

\section{Constructivism and Special Collections}

To relate the constructivist approach to learning and special collections, literature published in library journals was consulted with specific references to classroom learning. This is in part due to the unique context and nature of teaching with special collections, where librarians may be embedded in a course or offer multiple reading room visits for a course. The multiple points of contact or visits mean that librarians or archivists can help students "construct" knowledge.

Although there are few studies that present quantitative data on the success of constructivism, there is a study with a mixed methods approach that is much closer to learning with special collections and archives. In the study, Cocciolo uses a project, the Digital Archive Creation Project, in a digital archives course for graduate students. He asked students to assess their perceived learning outcomes to gauge the success of their learning experience. ${ }^{31}$ Students were assigned to groups to bring in the social aspect of constructivism, and they received hands-on experience with digitizing materials for the assignment. "As suggested by constructionist theory, ${ }^{32}$ the students iteratively built the digital archive and had a tangible artifact to discuss and demonstrate to their greater social network." ${ }^{33}$ This study demonstrates

27. Cooperstein and Kocevar-Weidinger, "Beyond Active Learning," 143.

28. Ibid.

29. Cooperstein and Kocevar-Weidinger, "Beyond Active Learning," 145.

30. Sizemore and Marcum, "Social Policy and Constructivism," 17-20.

31. Anthony Cocciolo, "Situating Student Learning in Rich Contexts: A Constructionist Approach to Digital Archives Education," Evidence Based Library and Information Practice 6, no. 3 (2011): 4-15.

32. Seymour Papert's Constructionist theory was greatly influenced by Piaget, and while this theory varies in that it was developed for learning with computers and lacked some elements of Piaget's theory, it is still based on the idea that learning is constructed. Christina E. Emeling, Towards Discursive Education: Philosophy, Technology, and Modern Education (Cambridge: Cambridge University Press, 2010), 57.

33. Cocciolo, "Situating Student Learning in Rich Contexts," 8. 
the success of the constructivist approach, as many students in Cocciolo's study expressed enthusiasm for the assignment in the qualitative feedback. The methodology in collecting both quantitative and qualitative findings strengthens his study. The quantitative results provided an overall view of the study, while the qualitative findings provided details and insight into the study. The one weakness, as the author admits in the article, is the small sample size of 31 students.

\section{Course Development}

In the fall of 2012, I designed and delivered a course titled "SMC300: Libraries, Special Collections and Archives." The course is connected to the Book and Media Studies (BMS) Program at the University of St. Michael's College at the University of Toronto. It was initially proposed and submitted for approval by the Director of the John M. Kelly Library in an effort to give undergraduate students more learning opportunities with the library's rare books collection and archival holdings. The archivist and rare books librarian were consulted to develop demonstrations and activities for the students during their visits to the Reading Room. There are 25 spots for undergraduate students entering their third or fourth year of the Book and Media Studies program. Students in the course, as well as the program, are often enrolled in dual programs of study. For example, there were students who were majoring in Book and Media Studies as well as Economics, although it was more common that students were studying BMS and English literature. The course took place once a week for two hours in a computer lab in the John M. Kelly Library as well as the Special Collections and Archives Reading Room. The course continues to be offered to Book and Media Studies students and has been taught by me for three years with the exception of $2015 .{ }^{34}$ The content and flow of the course were developed based on the idea that research with special and archival collections was a primary objective. Faculty members from the Book and Media Studies program were consulted along with the Archivist. Through discussions and mentoring, the faculty members and archivists provided guidance on content. The literature was pulled from my own learning experiences and research.

\section{Constructivism in Action}

This section explores four activities used in the course to align with the four main themes that emerge from constructivism. The discussion is framed around the following constructivist characteristics:

1. Connection between prior knowledge and new knowledge;

\footnotetext{
34. A sessional (a contract instructor) was hired to teach the course for one term to cover my maternity leave. The instructor held a PhD in Medieval Studies. I met with the instructor before leaving to discuss the activities and the course content. The instructor incorporated some elements into her version of the course.
} 
2. Social interaction between students or students and the instructor;

3. Real-life tasks or experiences that relate to new knowledge; and

4. Activities that prompt reflection on one's own learning and experience $(\mathrm{s}) .^{35}$

Constructivist strategies employed in the classroom can vary, and not every type of strategy is required to be implemented in teaching. The best way to approach constructivism is to choose one to two strategies and build the class structure to explore different ways to engage your students.

\begin{tabular}{|c|c|}
\hline \multicolumn{2}{|c|}{$\begin{array}{l}\text { TABLE } 1 \\
\text { Constructivist Features with Activities from the Course }\end{array}$} \\
\hline Constructivist Approach & Activities \\
\hline $\begin{array}{l}\text { Connection between prior } \\
\text { knowledge to new knowledge. }\end{array}$ & $\begin{array}{l}\text { - Paraphrase and provide examples of } \\
\text { "primary sources as a concept." } \\
\text { Analyze research articles that use special } \\
\text { collections and identify the structure and } \\
\text { research methods used by the researcher(s). }\end{array}$ \\
\hline $\begin{array}{l}\text { Social interaction between students } \\
\text { or students and the instructor. }\end{array}$ & $\begin{array}{l}\text { Describe and develop a research topic } \\
\text { through in-class discussions with peers. }\end{array}$ \\
\hline $\begin{array}{l}\text { Real-life tasks or experiences that } \\
\text { relate to new knowledge. }\end{array}$ & $\begin{array}{l}\text { Create an exhibit proposal to demonstrate } \\
\text { how research skills can be applied in a work- } \\
\text { related scenario. } \\
\text { Apply Sheehan's Preservation Framework }{ }^{\star} \text { to } \\
\text { select rare books. }\end{array}$ \\
\hline $\begin{array}{l}\text { Activities that prompt reflection } \\
\text { on one's own learning and } \\
\text { experience(s). }\end{array}$ & $\begin{array}{l}\text { Reflect on one's research experience in a } \\
\text { creative format, a zine. }\end{array}$ \\
\hline \multicolumn{2}{|c|}{$\begin{array}{l}\text { *Jennifer K. Sheehan, "Making the Most of What We Have: A Framework for Preservation } \\
\text { Management in Rare Book Collections," RBM: A Journal of Rare Books, Manuscripts, and Cultural } \\
\text { Heritage } 10.2 \text { (2009): 111-21. }\end{array}$} \\
\hline
\end{tabular}

In this particular case, I selected the constructivist activities after reviewing feedback from the course evaluations in my first year of teaching the course. For example, students often struggled with "primary sources" as a concept but had a basic definition. As a result, building on prior knowledge would be an excellent opportunity to shift students' understanding of primary sources.

35. David Wrap and Maureen Lewis, Extending Literacy: Children Writing and Reading Non-Fiction (New York: Routledge, 1997); Fosnot and Perry, "Constructivism: A Psychological Theory," 33-34; Pritchard, Ways of Learning. 


\section{Characteristic 1: Connection between Prior Knowledge and New Knowledge}

Since the course's inception, I observed that students struggled to identify primary sources for their topic. They typically focused on the type or media form; for example, students would look for letters, diaries, or items "that looked old" rather than examining their topic's context and identifying relevant sources through research. When I conducted a presurvey with the students in 2013, they often provided an object-based definition, where they listed items such as newspapers, diaries, letters, and old books. I wanted to build on this prior knowledge and expand on it by redefining primary source as "an exact and conditional category." 36 This concept takes a holistic approach in defining a primary source, whereby students are encouraged to examine their context and conduct research before identifying a primary source.

Hofer, Townsend, and Brunetti write that "the same source could be considered primary material in one context and shift to secondary when viewed through a different or temporal lens." ${ }^{37}$ By introducing "primary sources" as a concept, students are able to develop their critical thinking skills by examining the historical context of their topic. Erickson explains that a "broad, integrating concept, or a conceptual-level question, acts as a conceptual filter for students to use in processing factual information." ${ }^{38}$ Moreover, she cites constructivism as a learning model that complements conceptbased learning since constructivism is the connection between concepts. ${ }^{39}$ Another reason for moving students away from a simple definition was to provide them with more freedom to explore unique research topics that may not include "conventional" types of sources, because our Book and Media Studies program explores all forms of media. Furthermore, students were encouraged to develop their own original research topic.

To connect students with the "primary source as a concept," scaffolding strategies were used throughout the course. Scaffolding is a technique used to observe and support the progression students make in their learning. ${ }^{40}$ The idea is that a teacher can provide facilitation or guidance through the learning experience to help students construct their own meaning. It can be an effective strategy when introducing new ideas to students that may prove troublesome or challenging. Two scaffolding strategies were used: the feedback technique and the modeling technique. ${ }^{41}$

36. Hofer, Townsend, and Brunetti briefly touch on teaching primary sources as a concept rather than a definition. It is presented as a frame to make it applicable in various courses, disciplines, and/or contexts. The purpose in using their work was to shift to more concept-based teaching as encouraged by the Association for College and Research Libraries (ACRL) Information Literacy for Higher Education Framework document. Hofer, Townsend, and Brunetti, “Troublesome Concepts and Information Literacy," 387-405.

37. Hofer, Townsend, and Brunetti, "Troublesome Concepts and Information Literacy," 403.

38. H. Lynn Erickson, Concept-Based Curriculum and Instruction for the Thinking Classroom (Thousand Oaks, Calif.: Corwin Press, 2007), 71.

39. Erickson, Concept-Based Curriculum, 34.

40. Alan Pritchard and John Woollard, Psychology for the Classroom: The Social Context (New York: Routledge, 2010), 38 .

41. Ibid., 42 . 


\begin{tabular}{|c|c|}
\hline $\begin{array}{l}\text { TABLE } 2 \\
\text { Scaffolding Features of the "Primar }\end{array}$ & y Sources as a Concept” Exercise \\
\hline Characteristics of Scaffolding ${ }^{\star}$ & Exercise \\
\hline Scaffolding provides clear directions. & $\begin{array}{l}\text { Instructions were explained in the lecture and on } \\
\text { the handout, and the activity was completed in } \\
\text { class so they could ask for clarification from the } \\
\text { instructor. }\end{array}$ \\
\hline Scaffolding provides purpose. & $\begin{array}{l}\text { The purpose of the exercise is to expand } \\
\text { students' understanding of primary sources } \\
\text { from definition to concept. }\end{array}$ \\
\hline Scaffolding keeps students on task. & $\begin{array}{l}\text { Students can apply the concept when searching } \\
\text { and selecting primary sources for their research } \\
\text { topics. }\end{array}$ \\
\hline $\begin{array}{l}\text { Scaffolding offers assessment to clarify } \\
\text { expectations. }\end{array}$ & $\begin{array}{l}\text { Students were assessed one to two weeks after } \\
\text { an exercise session. }\end{array}$ \\
\hline $\begin{array}{l}\text { Scaffolding points students to worthy } \\
\text { sources. }\end{array}$ & $\begin{array}{l}\text { Students will be able to identify media sources } \\
\text { and artifacts beyond letters, diaries, newspapers, } \\
\text { and the like. }\end{array}$ \\
\hline $\begin{array}{l}\text { Scaffolding reduces uncertainty, } \\
\text { surprise, and disappointment. }\end{array}$ & $\begin{array}{l}\text { Students are introduced to the new concept } \\
\text { through gradual steps and guidance from } \\
\text { the instructor over a period of two months, } \\
\text { depending on students' success. Assessments } \\
\text { were announced one to two weeks beforehand } \\
\text { so that students could contact the instructor for } \\
\text { follow-up. }\end{array}$ \\
\hline Scaffolding delivers efficiency. & $\begin{array}{l}\text { Exercises did not go beyond } 15 \text { minutes. The } \\
\text { topic was presented and discussed for } 30 \\
\text { minutes. }\end{array}$ \\
\hline Scaffolding creates momentum. & $\begin{array}{l}\text { Reading room visits to view different types of } \\
\text { sources and lectures on archival research keep } \\
\text { students focused on the topic and its application. }\end{array}$ \\
\hline
\end{tabular}

The feedback technique involves providing continual feedback throughout the course or lesson. This may require multiple informal assessments such as quizzes (usually with no grade value) and providing feedback to students or discussions where students share their thoughts on the topic so far. ${ }^{42}$ In the course, formative assessments ${ }^{43}$ were used throughout the first few weeks of the course, up to two months. By two months, students should be working on their research and readying their papers for submission. In the first exercise, I provided students with a research topic

42. Ibid.

43. Formative assessment refers to the use of multiple informal exercises or activities used to gauge students' progression. 
and asked them to identify relevant primary sources based on the context provided to them each week. By the last exercise, students were asked to construct their own research topic and relevant resources. They must provide an explanation for their choices. The aim of the exercise was to move students toward the understanding and application of the concept whereby contextual information (time, place, event, or discipline) is an important aspect in determining the source(s). Moreover, the level of difficulty, depending on their progress, increased to challenge their understanding of the concept. By the end, students were creating their own research topics, identifying relevant primary sources, and able to explain their choices. Students submitted their exercises, and I provided feedback on their exercises each week. If I noticed that students struggled with a particular aspect of the concept, such as identifying contextual information, I would change my lesson plan to address the gap in knowledge and provide students with another exercise. The continual feedback can help guide students as well as help identify gaps in understanding.

A second scaffolding strategy, modeling, was used to further develop students' understanding and application of identifying relevant primary sources. The modeling technique was used to show students how academic researchers used primary sources for their research. The essence of the idea is that students are modeling themselves to what they observe; in this case, what they observe in the research literature ${ }^{44}$ Bandura writes that "most human behavior is learned observationally through modeling; from observing others one forms an idea of how new behaviors are performed, and on later occasions this coded information serves as a guide for action." ${ }^{35}$ Students read an article that was relevant to the type of primary sources they were interested in using for their research paper (see appendix A). They analyzed these peer-reviewed articles that used various types of sources such as scrapbooks, diaries, and the like. Students identified different parts and structures of the article and analyzed how a researcher used the type of source for research. The purpose of the exercise was for students to model or learn from the researchers' methods.

Scaffolding students' understanding of primary sources proved to be a challenge. It is important to note that learning should not be treated as a linear process; rather, it is a series of steps where students move forward and back multiple times. The problem with scaffolding is that often the learners and teachers expect that students will progress at the same rate. This is a myth. The biggest hurdle with this approach is tending to the students' progression. Some students progressed with each class, while some struggled with the concept throughout the course. If a majority of the class is struggling, the content should be presented in a different way. However, only a few students indicated that they found the material difficult,

44. Pritchard and Woollard, Psychology for the Classroom, 42.

45. Albert Bandura, Self-efficacy: The Exercise of Control (New York: W.H. Freeman, 1997), 22. 
and this was addressed through one-on-one appointments and discussions to meet the individual learning needs. In addition, scaffolding takes time and effort on the teacher's end. A good teacher constantly gauges students' knowledge and adjusts the course content and activities as they progress.

\section{Characteristic 2: Social Interaction between Students}

Typically, undergraduate students who are enrolled in the Books and Media Studies program attend lectures in their junior and sophomore year that range from 100 to 1,000 students. Due to the size of the lectures, often these students do not have an opportunity to write a research essay. Professors who teach those large class sizes lack resources to teach and grade students on how to develop and write a research paper. As a result, many students who were enrolled in the SMC300 course expressed hesitation in completing the research paper assignment. One of the biggest struggles with the students in the course was the development of a research topic. Initially, students booked one-on-one appointments to discuss their research topics. While the personalized support to address students' questions was helpful, it was not a sustainable method for me. Students seemed to wait for direction rather than try to develop the topics on their own. As a result, I incorporated discussions throughout the course to help each student develop a research topic and evaluate primary sources. During the reading room visits, I asked the students to discuss their ideas and thoughts on their analyses of the selected items, as well as their ideas for research topics.

I implemented a discussion-based activity for reading room visits so that students could compare and get feedback on their observations and evaluation of the primary sources they had selected for their research topics. Rather than dictate the answers through a structured lecture, students had an opportunity to explore and discuss their findings with other students. The social interaction and discussion among students informed or helped students form a perspective on a topic. ${ }^{46}$ Moreover, it helped students develop a critical lens or encouraged students to investigate a primary source further.

One of the inquiry-based discussions I developed for this course was referred to as the "blind date activity." Inquiry-based discussions took a semistructured approach, whereby students were provided with an interpretive question and a series of factual questions. An inquiry-based discussion has the following characteristics: ${ }^{47}$

- The instructor is a facilitator and allows the students to engage in conversation. She remains neutral to the discussion.

46. Pritchard, Ways of Learning, 33.

47. Kirsten K. Madden, "Engaged Learning with the Inquiry-Based Question Cluster Discussion Technique: Student Outcomes in a History of Economic Thought Course," Southern Economic Journal 77, no. 1 (2010): 225-26. 
- The basic question is interpretative, encourages a student to examine concepts, and encourages students to analyze ideas.

- Factual questions help to further inquiry into the basic question.

- Students compare and debate their differing interpretations to gain more perspective on their opinion/idea.

Students were set up on a series of "dates" with select items from the special collections and archives. The students received short profiles of the items that included basic information such as date of publication, place of publication, creator information (if any), and format. During the "date" with the item, students had to ask several questions about the item. For example, a student may ask a travel diary, "What is its purpose? Why is it here?" Students also received readings to help them formulate questions. The analogy was used to help students understand the importance of inquiry; like a blind date, the purpose is to "get to know someone" better by asking questions to see if it is a good match. In this particular case, the purpose was to select an item and develop a research idea/topic. Students received the following instructions (see appendix B for the question guide):

1. You will be given a preview of the items during a lecture and you are allowed to view the digitized version of the item ahead of time.

2. You should select one item and must explore the question, "What research ideas or topics can you generate from this item?" with each item.

3. You will be given a series of questions based on the assigned course reading to analyze the item's content as a primary source;

You will compare your ideas/findings and notes with a group of your peers (5-6 students).

4. You may set up a second date with the item to further analyze and explore topic ideas.

These questions acted as prompts so that students would evaluate the primary sources with a critical lens. The evaluation is followed by a group discussion. This step is likened to calling friends and talking about their blind dates, breaking down the details and getting feedback.

The challenge with discussion-based activities is that it requires facilitation from the instructor to help guide the conversation. Moreover, some students may not engage in the discussion and may need encouragement from the instructor. In a large class, the instructor may need to visit each group to keep the topic on track or encourage passive students to share their research topics. This can take up a lot of class time or the instructor may not get to every group by the end of the class. 
If discussion-based activities were used for large class sizes, it would be helpful to supplement or include the use of online forums in the learning management system for the course (such as Moodle, Blackboard, Canvas, and others) to conduct an asynchronous discussion.

\section{Characteristic 3: Real-Life Tasks or Experiences That Relate to New Knowledge}

In a majority of the reflections submitted, students perceived the research produced in the course as merely a requirement. They did not see how the research they produced using rare books and archival materials applied beyond their coursework. Some students wrote that, while the research experience was interesting, it was difficult to envision the application of these skills in real life. By 2014, I developed an assignment (see appendix C) that came in the form of an exhibit proposal. This allowed students to apply their research skills to a real-life scenario (see table 3).

I asked the students to conduct research on rare books for an exhibit. ${ }^{48}$ The assignment allowed students to apply their understanding of research with rare books in a different and new context. In a survey after the course, all students indicated that they had never presented research with primary sources as an exhibit proposal or had the opportunity to create an exhibit. A Museum Studies graduate student visited the class and presented basic exhibition theory to students. In addition, the chair of the exhibit committee gave students a tour of the John M. Kelly Library's current exhibits. Students were given time to ask questions about the exhibits. Before students submitted their exhibit proposal, they were asked to apply Jennifer K. Sheehan's Preservation Framework to enhance the authenticity of the task. Students examined select items they were going to display using Sheehan's Framework. ${ }^{49}$

The challenge with authentic tasks is that they may not be familiar forms of learning in an academic environment. For the course, students indicated that they felt anxiety or were nervous about the outcome of the assignment, due in part to their lack of experience with completing a unique project such as the exhibit proposal. However, if a teacher provides clear instructions, guidance, and resources such as sample exhibit proposals, it can support students' new experiences.

48. Baviskar, Hartle, and Whitney write that the "application of the new construct could be in the form of quizzes, presentations, group discussions, or other activities where the students compare their individual constructs with their cohorts' or with novel situations. In addition to checking the validity of their constructs, application allows the student to further define the interconnectedness of the new knowledge to a greater variety of contexts, which will integrate the new knowledge permanently." Sandaya N. Baviskar, R. Todd Hartle, and Tiffany Whitney, "Essential Criteria to Characterize Constructivist Teaching: Derived from a Review of the Literature and Applied to Five Constructivist-Teaching Method Articles," International Journal of Science Education 31, no. 4 (2009): 544.

49. Jennifer K. Sheehan, "Making the Most of What We Have: A Framework for Preservation Management in Rare Book Collections," RBM: A Journal of Rare Books, Manuscripts, and Cultural Heritage 10, no. 2 (2009): 111-21. 


\begin{tabular}{|c|c|}
\hline \multicolumn{2}{|c|}{$\begin{array}{l}\text { TABLE } 3 \\
\text { Characteristics of an Authentic Task in the Exhibit Proposal Assignment }\end{array}$} \\
\hline $\begin{array}{l}\text { Characteristics of } \\
\text { Authentic Tasks }\end{array}$ & $\begin{array}{l}\text { Exhibit Proposal } \\
\text { Assignment }\end{array}$ \\
\hline $\begin{array}{l}\text { Authentic tasks are ill defined and } \\
\text { require a student to define the tasks and } \\
\text { subtasks needed to complete the activity. }\end{array}$ & $\begin{array}{l}\text { Students receive an exhibit template as a guide. } \\
\text { However, students decided what tasks were } \\
\text { necessary to create an exhibit proposal. }\end{array}$ \\
\hline $\begin{array}{l}\text { Students can investigate authentic tasks } \\
\text { over a sustained period of time. }\end{array}$ & $\begin{array}{l}\text { Students were introduced to exhibit theory, } \\
\text { shown different exhibits in the library and } \\
\text { provided resources throughout the course. } \\
\text { Moreover, students were asked to apply } \\
\text { Sheehan's Preservation Framework to the } \\
\text { select items. }\end{array}$ \\
\hline $\begin{array}{l}\text { Authentic tasks can be integrated and } \\
\text { applied across different subject areas and } \\
\text { lead beyond domain-specific outcomes. }\end{array}$ & $\begin{array}{l}\text { Students are looking through the lens of } \\
\text { a designer, audience, and researcher to } \\
\text { understand the various roles involved in creating } \\
\text { and consuming an exhibit. }\end{array}$ \\
\hline $\begin{array}{l}\text { Authentic tasks are seamlessly } \\
\text { integrated with assessment. }\end{array}$ & $\begin{array}{l}\text { The assignment demonstrates students' ability } \\
\text { to conduct research and present it in a different } \\
\text { format and audience. }\end{array}$ \\
\hline $\begin{array}{l}\text { Students create accomplished products } \\
\text { valuable in their own right. }\end{array}$ & $\begin{array}{l}\text { Students created a final proposal document } \\
\text { with images, exhibit text, and design ideas. }\end{array}$ \\
\hline $\begin{array}{l}\text { Authentic tasks allow competing } \\
\text { solutions and diversity of outcome. }\end{array}$ & $\begin{array}{l}\text { Students' design and topic ideas were unique, } \\
\text { and students created their own interpretations } \\
\text { of the items and theme. }\end{array}$ \\
\hline \multicolumn{2}{|c|}{$\begin{array}{l}{ }^{\star} \text { Characteristics listed in the table are cited directly from the following book chapter: Jan Herrington, } \\
\text { Thomas C. Reeves, and Ron Oliver, "Authentic Learning Environments," in Handbook of Research on } \\
\text { Educational Communications and Technology, J. Michael Spector, M. David Merrill, Jan Elen, and M.J. } \\
\text { Bishop, eds. (New York: Springer, 2014), } 404 .\end{array}$} \\
\hline
\end{tabular}

\section{Characteristic 4: Activities That Prompt Reflection on One's Own Learning}

One of the greatest challenges with teaching an undergraduate course is creating an experience that contributes to the student's overall learning. Some students can easily forget what they learn, due to the duration of the term combined with the other in-class and extracurricular commitments students juggle. To ensure that students take away valuable lessons from the course, it is important to ask students to take time to reflect on their experience.

Metacognition, or one's awareness of one's learning and experience, is another important feature of the constructivist learning theory. Reflection allows students to step back at the end of a lesson or course and identify successes as well as gaps in their experiences. By encouraging students to reflect on their experiences, students are investing time and effort in their learning. Often, the length of a fall-term course does not allow much time for students to reflect and think about their learn- 
ing. As stakeholders in their own education, it is vital that time be set aside to allow students to understand and make sense of their experiences. Once they acknowledge what they have learned, they are likely to revisit the same topic or remember the concepts and content presented to them in the course.

A quality summative reflection assignment should include prompts to engage students in deeper analysis of their learning experience. A simple play-by-play of their research steps is considered superficial because it requires little thought, compared to a reflection that discusses challenges from the experience and solutions moving forward. The following questions from the $4 \mathrm{R}$ Reflective Scale can help students write quality reflections: ${ }^{50}$

- How would I deal with this next time?

- What might work and why?

- Are there different options?

- What might happen if...?

- Are my ideas supported by theory?

- Can I make changes to benefit others?

The challenge with reflection assignments is that it requires a great deal of time to write a meaningful response. Moreover, students are not taught how to effectively reflect; as a result, many of the assignments often become a summary of actions rather than an analysis of missteps and lessons from mistakes. Students require practice and prompting when completing a reflection assignment. Formative reflections can help inexperienced students develop reflection skills.

In this particular course, students received formative reflection activities after a class or visit (see appendix D) that would allow them to reflect on the experience as well as inform the instructor of their progress. In the past, this was often assigned as a reflection paper; the completion rate for reflection papers often ranged between $50 \%$ and $60 \%$. In early evaluations, students cited that they were exhausted from writing and needed a break. As a result, in 2014, I assigned the reflection paper as a zine (see appendix E). For students who were unfamiliar with the zine medium, examples were provided in the class. Interestingly, most students still took a narrative approach in their reflections.

50. Questions are from the 4R Reflective Scale by Mary Ryan and Michael Ryan. See Mary Ryan and Michael Ryan, "A Model for Reflection in the Pedagogic Field of Higher Education," in Teaching Reflective Learning in Higher Education, ed. Mary Elizabeth Ryan (Cham, Switzerland: Springer International Publishing, 2015), 15-27. 


\section{Future Studies}

Another model of learning theory, inquiry-based learning (IBL), is worth exploring, although it has similarities to constructivism $;{ }^{51}$ this comes as no surprise because IBL is rooted in constructivism. IBL focuses on inquiry and, much like constructivism, it is a learner-centered theory. Students engage in learning through questions, interaction, and discussion. By allowing each student to develop a question and pursue it, in theory, it helps to engage the students in learning and constructing new knowledge. The instructor acts as a guide, prompting the students to think critically and to reflect on each step of the learning process.

This approach has great potential in engaging undergraduate students in research through a critical lens with special collections and archives. Moreover, undergraduate students in independent study or thesis-based courses that require use of special collections could benefit from IBL. There is some literature that focuses on the application of IBL in the humanities ${ }^{52}$ as well as the archives. ${ }^{53}$ It would be worth conducting a study on the learning experiences of undergraduate students in independent study or research seminars that use this model.

Independent studies at the University of Toronto focus on the exploration of a research topic initiated by an undergraduate student. This is an opportunity for special collections librarians to provide mentorship and guidance as well as apply the inquiry-based approach. In IBL, the teacher acts as a guide and, as a result, develops a mentorlike role. The approach involves facilitating discussion around a research topic to inspire research into the topic. The teacher plays a more collaborative role with the student or learner, creating an interactive learning environment. ${ }^{54}$ With

51. Inquiry-based learning (IBL) includes social interaction, reflection, independent learning, and construction of knowledge. These characteristics are very similar to constructivism; however, IBL and constructivism differ in that the instructor has much less control or is less able to predict the results of an activity in IBL. Moreover, discussion is heavily emphasized, along with the instructor's role as a facilitator who would provide prompts to push students to further question and discuss a topic. Norman Vaughan Steven Prediger, "Investigating the Role of an Inquiry-Based Approach to Learning," in InquiryBased Learning for the Arts, Humanities, and Social Sciences: A Conceptual and Practical Resource for Educators (Bingley, U.K.: Emerald Group Publishing, 2014), 27-52.

52. The 2014 publication Inquiry-Based Learning for the Arts, Humanities, and Social Sciences: A Conceptual and Practical Resource for Educators offers many case studies and discussion for applying IBL in the humanities. Watts' chapter in particular provides practical tips in applying the IBL approach in the context of historical research. Linda S. Watts, "Historical Detectives at Work: A Casebook Approach to Guided-Inquiry for Undergraduate Learning," in Inquiry-Based Learning for the Arts, Humanities, and Social Sciences: A Conceptual and Practical Resource for Educators, eds. Patrick Blessinger and John M. Carfora (Bingley, U.K.: Emerald Group Publishing Limited, 2014), 127-46.

53. Rockenbach discusses the application of the inquiry-based learning using case studies in the context of teaching archival research. She provides details in the development of the assignments and lessons. Barbara Rockenbach, "Archives, Undergraduates, and Inquiry-Based Learning: Case Studies from Yale University Library,” American Archivist 74, no. 1 (2011): 297-311.

54. Patrick Blessinger and John M. Carfora, "Innovative Approaches in Teaching and Learning: An Introduction to Inquiry-Based Learning for the Arts, Humanities and Social Sciences," in Inquiry-Based Learning for the Arts, Humanities and Social Sciences, eds. Patrick Blessinger and John M. Carfora (Bingley, U.K.: Emerald Group Publishing Limited, 2014), 3-26. 
this approach, special collections librarians and archivists can play a more active teaching role as well as getting involved in unique undergraduate research projects.

\section{Conclusion}

This article outlines basic features of the constructivist approach in a special collections context; however, it is important to note that constructivism can be a complex learning theory with many connections to other variations of the theory. Moreover, the way individuals teach and learn is dependent on context and experience. It is important to explore theory and consult research further before applying learning theories in the classroom. Small changes or introducing one or two activities followed by student feedback can be a good way to explore a learning theory. One important note is that learning itself is messy and, at most times, nonlinear. Students advance and regress as part of their learning experiences. As teachers, part of the onus is on us to ensure that we observe these steps and missteps and adapt to their learning needs. This means switching up the activities and applying different strategies to engage students in research and critical thinking. The aim of taking a constructivist approach is to encourage undergraduate students to take a more active role in using items from the special collections and archives. Moreover, it can encourage them to interact with their librarian or archivist and view her or him as a teacher rather than a gatekeeper. The application of learning theory can create positive experiences by breaking down seemingly complicated steps and analyses of the items. This proved to be the case in my context, as demonstrated in the university's course feedback form. Some students wrote:

"Silvia really made an effort to provide the best learning experience and environment possible, and that really enhanced my overall experience in the course. There was a nice variety of assignments and experiences (visiting the Reading Room, etc.) that kept the course interesting, and provided for learning in several different settings and ways."

"Silvia is patient with her students and she explains difficult material in an easy to understand manner."

"Professor Vong was very in-tune with different student's learning abilities. She was very accommodating and understanding of each individual student..."

By scaffolding concepts and content, setting up socially interactive activities, situating the students through applied practice, and encouraging students to reflect on the learning experience, it created a comprehensive and engaging research experience in the special collections and archives. 


\section{APPENDIX A. Modeling Exercise}

Select an item relevant to your research and read the assigned article. You will be asked to analyze how the researcher used the items for his or her research. Handouts will be given out in class to guide your analysis.

Diary: Paperno, Irina. "What Can Be Done with Diaries?” Russian Review 63, no. 4 (2004): 561-73.

Rare Book: Ferris, Ina. "Book Fancy: Bibliomania and the Literary Word." KeatsShelley Journal 58 (2009): 33-52.

Penmanship Book: Eaton, William E. "American School Penmanship: From Craft to Process." American Journal of Education 93, no. 2 (1985): 252-67.

Scrapbook: Buckler, Patricia P., and C. Kay Leeper. "An Antebellum Woman's Scrapbook as Autobiographical Composition." Journal of American Culture 14, no. 1 (2004): $1-8$.

Type Specimen: Johnson, A.F. "The Type-Specimen Books of Claude Lamesle and Nicolas Gando.” The Library, s4-XVIII.2 (1937), 201-11.

Institutional Publications: Bobinski, George S. "Carnegie Libraries: Their History and Impact on American Public Library Development." ALA Bulletin 62, no. 11 (1968): 1361-67.

Your selected item:

Article title:

Research question/thesis of the article:

Main points of the article:

1.

2.

3.

Primary sources used in the article (please name the author and title):

How was/were the primary source(s) used in the research article?

Can you identify any gaps in the research? 


\section{APPENDIX B. Discussion Questions Guide}

The assigned reading for the Reading Room visit was:

Ziemann, Benjamin, and Mariam Dobson. "Introduction." In Reading Primary Sourc-

es: The Interpretation of Texts from 19th and 20th Century History, edited by Miriam

Dobson and Benjamin Ziemann. New York: Routledge, 2009. 1-18. PDF file.

Basic Questions:

- What research ideas or topics can you generate from each item?

Factual Questions:

- What kind of contextual information can you determine from the text or artifact?

$>$ For example, a text produced in 18th-century in Europe may have influences from the Age of Enlightenment.

- What is the type or purpose of the text or artifact?

- Who is the narrator/creator of the text or artifiact?

- Does the text or artifact use biased language?

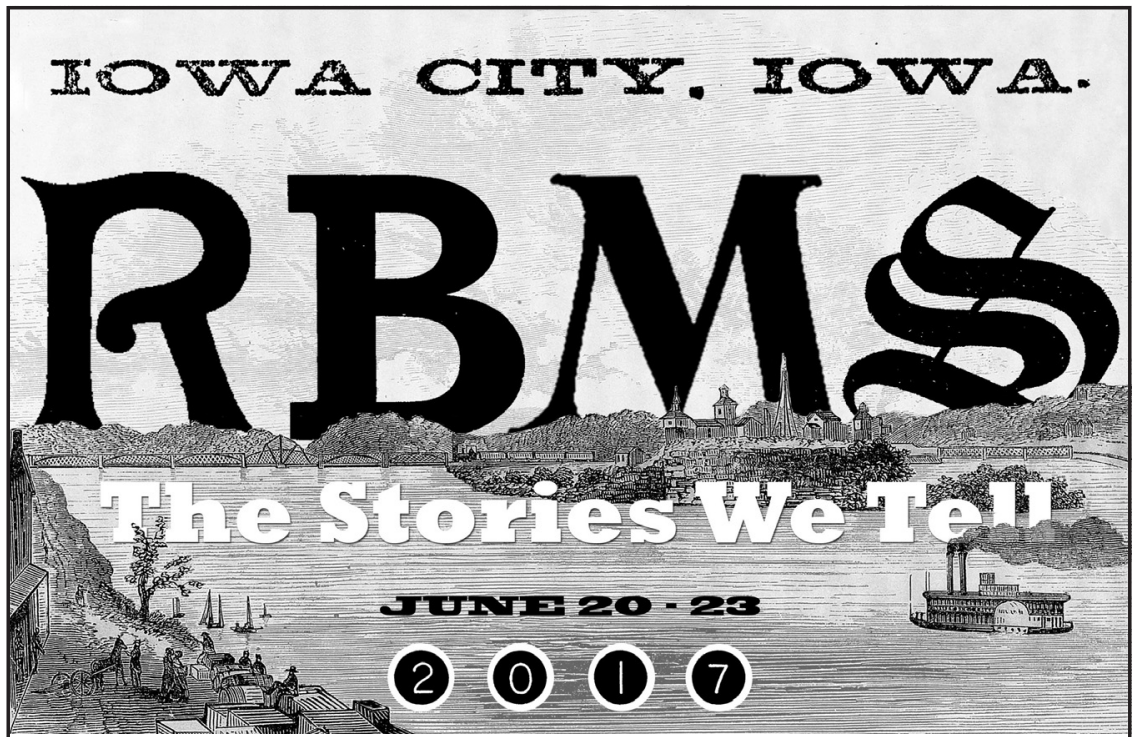

The Stories We Tell focuses on storytelling as practice and metaphor in the mission and daily work of special collections. At this conference, we will share our community's stories, while imagining future narratives for special collections in a rapidly evolving cultural and technological landscape.

We invite you to join the conversation June 20-23, 2017 in Iowa City, IA, a UNESCO City of Literature with a vibrant literary and book arts community. This easy-going and open-minded Midwestern town provides an ideal environment for an intimate and productive inquiry into the role and nature of storytelling in Special Collections. See http://conference.rbms.info/2017/ for details. 


\section{APPENDIX C. Exhibit Proposal Assignment}

Apply your research skills in a real scenario. You are a librarian or archivist and have been tasked with designing an exhibit to showcase one or two special items from the Rare Book Collection or Archives. If you do more than one item, the items must be connected by a common theme. Before you can proceed with creating the exhibit, you must submit a proposal to an exhibit committee.

You must use items from the Rare Books, Archival and Manuscript Collections. Select items from the Flickr page: https:/ /www.flickr.com/photos/125182944@, N07/sets/ 72157644620877268.

In your proposal, you must include the following:

- Introduction: Outline your theme, target audience, and purpose.

- Content: Include the text that will accompany the item and images. You must include references or works-cited list.

- Physical layout of the exhibit: Pick one or two cabinets and provide an initial layout of the cabinet cases, including item, image, or text/ content locations.

- Environmental Assessment: Visit the Kelly Library Exhibit Area and discuss some preservation concerns.

Writing Guidelines:

- Length of the proposal: 5 to 6 pages (double spaced) including diagrams/images.

- Citations should be in Chicago, APA, or MLA.

- $\quad$ Font size should be Times New Roman or Cambria (12 point).

- You must include at least 4-6 sources and must be scholarly articles or books.

- Your secondary sources need to be scholarly or from a peer-reviewed journal.

- The content and environmental assessment must be written in sentences.

- You must write formally (no slang, acronyms, or the use of "I").

- See rubric for assessment guidelines. 


\section{APPENDIX D. Sample Reflection Activities for Formative Assessment}

3-2-1 Activity:

- What were three things you learned today?

- What were two challenging things about the class?

- What one question do you have for the instructor?

Muddiest Point:

What was the muddiest point in today's lecture?

Think, Pair, and Share:

1. Read the question on the screen and think about your answer (5 minutes).

2. Find another student and discuss your answer (7-10 minutes).

3. Share your answer with the class.

Sentence Stems:

Complete the following sentences: I am most unclear about...

\section{Safe Questions:}

Write down a question you have for the instructor related to the lecture, assignments, or readings. Do not put your name on this slip; this is meant to be anonymous! Put your question in the box. The instructor will set time aside to answer some of these questions at the end of the class.

\section{Metaphors:}

Use a metaphor to describe your learning experience. For example:

Today's lesson was like a maze, I know there's an exit, I'm just not there yet.

Today's lesson was like a buffet, I felt overwhelmed with choices and wish it was focused on just a few food items. 


\section{APPENDIX E. Zine Reflection}

Description of Assignment: Reflect on your research experience through the creation of a zine or mini-comic on a topic related to your experience. Your reflection zine can include a variety of things such as: poems about the experiences, written text, images, drawings, or whatever you can imagine! There is no limit for words, but content and ideas need to be clear. If necessary, you can accompany your submission with an explanation.

The below images are excerpts from a student's zine reflection. This is an example of an exemplary reflection. The student explores ideas on research as well as her experience on working with Sheila Watson's archival fond.

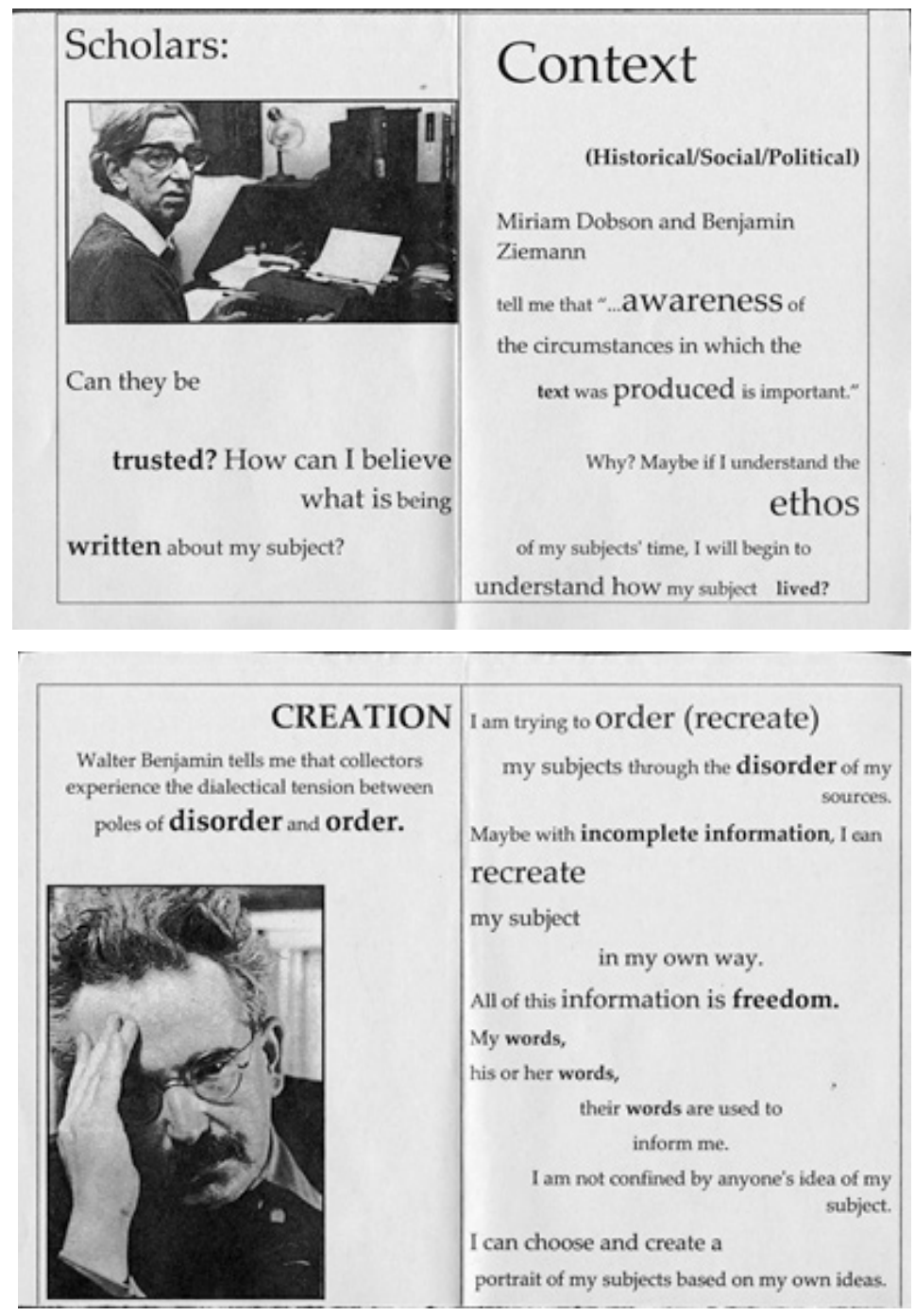

